\title{
ANTISTREPTOLYSIN CONTENT OF THE BLOOD SERUM IN RHEUMATIC FEVER AND RHEUMATOID ARTHRITIS
}

\author{
By WALTER K. MYERS AND CHESTER S. KEEFER \\ (From the Thorndike Memorial Laboratory, the Second and Fourth Medical Services \\ (Harvard) of the Boston City Hospital, and the Department of Medicine, \\ Harvard Medical School, Boston)
}

(Received for publication October 11, 1933)

Generally speaking immunity to streptococcal infection is slight and of short duration. One of the reasons for this is the great invasive powers of the streptococci, and the irregularity with which demonstrable antibodies are formed in patients with streptococcal infection. Immune bodies can, however, be demonstrated in some patients following streptococcal infection, and attempts have been made to show that there are several types, which may be divided into three groups: antibacterial, antitoxic, and allergic.

Antibacterial immunity is the result of the body's response to the streptococci themselves, and the presence of such antibodies is demonstrated by finding antistreptococcal agglutinins or precipitins in the blood serum. Using these methods, Schlesinger and Signy (1), and Coburn and Pauli (2), have shown that immunity of this type can be demonstrated for a very short time following infection, and, indeed, we have found in common with others that agglutinins may be formed very irregularly following streptococcal infection. It should be mentioned here that caution must be used in interpreting the significance of streptococcal agglutinins unless the precautions, as outlined by Tillett and Abernethy (3), are followed.

Antitoxic immunity depends, not only upon the response of the individual, but also on the nature and amount of toxic substances or toxins elaborated by streptococci. It is recognized that toxins vary in their specificity and many streptococci either produce very little toxin, or none that can be demonstrated. The Dick test and the neutralization of Dick toxin have offered methods of demonstrating antitoxic immunity, and although the technique is somewhat difficult and lacking in precision, its employment has provided useful information.

Allergic reactions to the products of the growth of the streptococci, as demonstrated by skin tests to the various chemical fractions, such as the nucleoprotein or toxic filtrates, have yielded information regarding the incidence of streptococcic infection in various conditions, and have provided another method for the study of immune reactions in such patients. 
Aside from these methods for studying immunity, Todd (4) (5) has recently called attention to a substance, antistreptolysin, which is present in the blood serum and is capable of neutralizing the hemolytic substance formed in vitro by hemolytic streptococci. He has found that following hemolytic streptococcal infections, this substance increases in amount in the blood serum. This method then, offers another means of investigating the response of the body to hemolytic streptococcal infection.

In previous papers by Keefer, Myers and Oppel (6), the presence of agglutinins and skin reactions to the nucleoprotein fraction of Streptococcus scarlatinae were studied in patients with rheumatic fever and rheumatoid arthritis, and in a group of miscellaneous hospital patients in an attempt to determine the relationship, if any, between streptococcal infection and these diseases. In pursuing the investigation further, we have studied the antistreptolysin content of the blood serum of two hundred and twenty patients at different times during the course of their disease. The types of disease these patients had are summarized in Table I and Figure 1.

In addition to determining the antistreptolysin titre of the serum, we also studied the agglutination reaction of the blood serum to the same

TABLE I

Antistreptolysin titre of human sera

\begin{tabular}{|c|c|c|c|c|c|c|c|c|c|}
\hline & 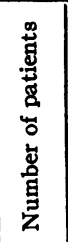 & 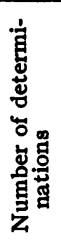 & 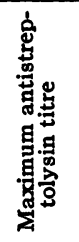 & 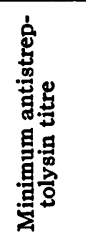 & 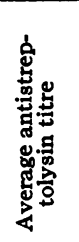 & 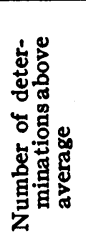 & 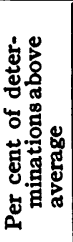 & 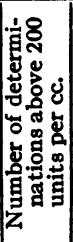 & 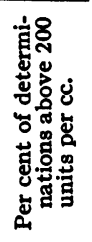 \\
\hline & & & $\begin{array}{l}\text { units } \\
\text { per cc. }\end{array}$ & $\begin{array}{l}\text { units } \\
\text { per cc. }\end{array}$ & $\begin{array}{l}\text { units } \\
\text { per cc. }\end{array}$ & $\begin{array}{l}\text { units } \\
\text { per cc. }\end{array}$ & $\begin{array}{l}\text { per } \\
\text { cent }\end{array}$ & & per cent \\
\hline $\begin{array}{l}\text { Normal individuals..... } \\
\text { Scarlet fever }\end{array}$ & 20 & 73 & 500 & 30 & 213 & 27 & 37.0 & 27 & 37.0 \\
\hline (Convalescent). & 71 & 71 & 5000 & 100 & 752 & 29 & 40.8 & 63 & 88.7 \\
\hline $\begin{array}{l}\text { Erysipelas............. } \\
\text { Acute respiratory infec- }\end{array}$ & 18 & 64 & 3000 & 50 & 598 & 17 & 26.6 & 42 & 65.6 \\
\hline $\begin{array}{l}\text { tions (hemolytic } \\
\text { streptococcus)..... }\end{array}$ & 19 & 31 & 800 & 40 & 356 & 14 & 45.2 & 22 & 71.0 \\
\hline $\begin{array}{l}\text { Miscellaneous strepto- } \\
\text { coccal infections... } \\
\text { Infections not caused by }\end{array}$ & 11 & 17 & 1000 & 40 & 300 & 6 & 34.5 & 6 & 34.5 \\
\hline & 14 & 29 & 500 & 50 & 210 & 10 & 34.4 & 10 & 34.4 \\
\hline Rheu & 33 & 204 & 2000 & 100 & 512 & 67 & 32.8 & 160 & 78.4 \\
\hline $\begin{array}{l}\text { Gonorrheal arthritis... } \\
\text { Miscellaneous types of }\end{array}$ & 16 & 30 & 500 & 50 & 208 & 10 & 33.3 & 10 & 33.3 \\
\hline $\begin{array}{l}\text { arthritis . . . } \\
\text { Rheumatoid (atrophic) }\end{array}$ & 5 & 12 & 300 & 50 & 105 & 1 & 8.3 & 1 & 8.3 \\
\hline arthritis & 13 & 61 & 800 & 20 & 196 & 14 & 23.0 & 14 & 23.0 \\
\hline TOTAI & 220 & 592 & 5000 & 20 & & & & & \\
\hline
\end{tabular}




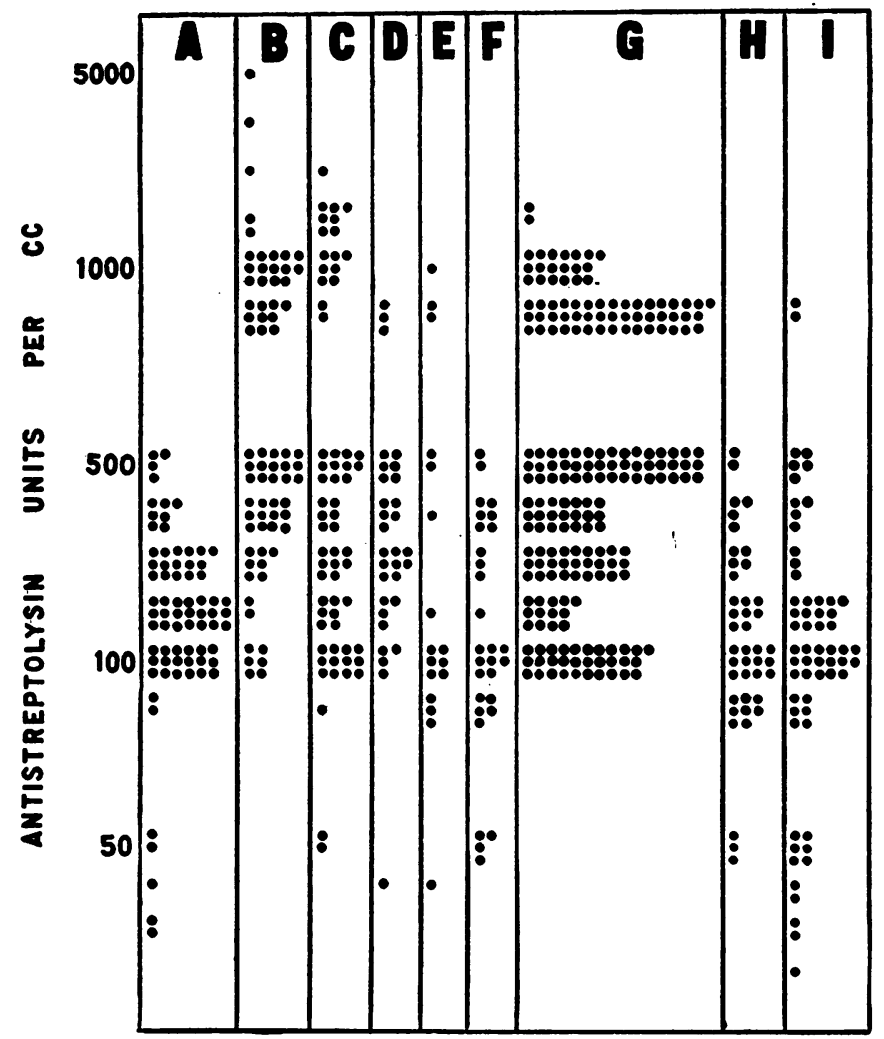

Fig. 1. Antistreptolysin Titre of Human Sera.

Each dot represents one determination- $A$, Normal individuals; $B$, Convalescent scarlet fever patients; $C$, Erysipelas patients; $D$, Patients with acute streptococcal respiratory infections; $E$, Patients with other infections caused by streptococci; $F$, Patients with infections not caused by streptococci; $G$, Rheumatic fever patients; $H$, Patients with rheumatoid arthritis; $I$, Patients with gonorrheal arthritis and miscellaneous forms of arthritis.

organism from which the hemolysin had been made. In a number, skin reactions to the nucleoprotein of the hemolytic streptococcus and to Dick toxin were tested in the same individuals.

\section{METHODS OF STUDY}

All patients were studied while being kept in the hospital. Blood was tested for its antistreptolysin content at different stages of the disease process, using the following technique.

Streptococcal hemolysin was prepared by a modification of the method described by Todd (4). Veal muscle infusion broth containing 2 per cent Difco proteose-peptone and 0.5 per cent sodium chloride adjusted to a $\mathrm{pH}$ of 8.0 was used. To this medium was added yeast extract ( 7 cc. per 100 
cc.) prepared from Mead's Powdered Brewers' Yeast. The media was inoculated from a six-hour culture of a hemolytic streptococcus (NY5) and incubated for sixteen hours at $37^{\circ} \mathrm{C}$. At first the culture was incubated under a vaseline seal but it was found that the yield of streptolysin was not enhanced by the anaerobic culture. The culture was centrifuged at high speed for 45 minutes to remove the organisms. The supernatant fluid was treated with 0.5 gram of sodium hydrosulphite and $1.0 \mathrm{cc}$. of normal sodium hydroxide to each $100 \mathrm{cc}$. The air was withdrawn by means of a water suction-pump for 30 minutes. The $\mathrm{pH}$ of the solution was then adjusted to 7.6 or 7.7 and the solution stored under vaseline in tubes in the icebox. The streptolysin used was of such potency that $0.2 \mathrm{cc}$. would completely hemolyze $0.5 \mathrm{cc}$. of a 5 per cent suspension of washed sheep cells in normal saline in conformity with the procedure of Todd (4).

The titration of the antistreptolysin of the sera was carried out after the sera had been inactivated for fifteen minutes at $56^{\circ} \mathrm{C}$. Dilutions of the serum in normal saline were prepared. The dilutions used were $1: 20$, $1: 30$, etc. to $1: 4000$ and $1: 5000$. To $1.0 \mathrm{cc}$. of each dilution was added $0.5 \mathrm{cc}$. of streptolysin solution. This was shaken and incubated for 30 minutes at $37^{\circ} \mathrm{C}$. One-half cc. of a 5 per cent suspension of washed sheep red blood cells in normal saline was added. The tubes were then shaken and incubated for one hour at $37^{\circ} \mathrm{C}$., being shaken again fifteen minutes after the addition of the sheep cells.

The titre of antistreptolysin of the serum tested is expressed in units as the reciprocal of the fraction of one cc. of serum just sufficient to inactivate $0.5 \mathrm{cc}$. of the streptolysin solution (Todd (5)). A unit of antistreptolysin may be said to be the amount necessary to inactivate 0.5 cc. of streptolysin solution of the potency prescribed above. For example, a given serum is said to contain twenty units per cc. when one cc. of the $1: 20$ dilution is the least amount necessary to inactivate $0.5 \mathrm{cc}$. of standard streptolysin solution.

At the time of each determination a horse serum of known antistreptolysin titre was used as a control. This was necessary in order to ascertain that the hemolysin was constant and potent.

\section{RESULTS}

There were made 592 determinations of the antistreptolysin titre of the blood sera from 220 individuals. Their ages varied from 5 to 84 years. It was not possible to show any correlation between the age of the individual and the titre of the antistreptolysin of the blood serum.

As controls, we studied normal individuals without streptococcal infection, horse serum obtained from horses that had been immunized against the streptococcus, and horse serum from horses immunized against other antigens. 
The normal individuals whose sera were studied were laboratory workers who did not present clinical features of any streptococcal infection during the period of observation. Two individuals were followed biweekly for 4 months. The blood sera of the other 18 normal individuals were studied every 4 weeks for a period of from 2 to 4 months. The results are summarized in Table $I$ and Figure 1 . Sera from the same individual varied from determination to determination, occasionally from one dilution to the adjacent one and rarely to the second dilution. In Table II this is demonstrated in 4 individuals.

TABLE II

Variation in antistreptolysin titres in four normal individuals over a period of five months

\begin{tabular}{|c|c|c|c|c|c|}
\hline \multirow{3}{*}{ Individual } & \multicolumn{5}{|c|}{ Antistreptolysin titres-Units per cc. } \\
\hline & \multicolumn{5}{|c|}{ Months } \\
\hline & 1 & 2 & 3 & 4 & 5 \\
\hline $\begin{array}{l}1 \\
2 \\
3 \\
4\end{array}$ & $\begin{array}{r}100 \\
30 \\
200 \\
100\end{array}$ & 30 & $\begin{array}{r}100 \\
50 \\
300 \\
100\end{array}$ & $\begin{array}{r}100 \\
40 \\
200 \\
100\end{array}$ & $\begin{array}{l}200 \\
300 \\
100\end{array}$ \\
\hline
\end{tabular}

In order to determine the differences between the antistreptolysin titre of the blood serum of horses immunized with hemolytic streptococci, and those immunized with other organisms, 16 specimens of blood serum were studied. The results are summarized in Table III.

It is seen that there are wide variations in both groups, but it is clear that the sera of horses immunized with streptococci showed a much higher titre with one exception than the sera from non-immunized animals. This

TABLE III

Antistreptolysin titre of horse serum

\begin{tabular}{c|c|c|c}
\hline Specimen & $\begin{array}{c}\text { Serum from horses immunized } \\
\text { with hemolytic streptococci }\end{array}$ & Specimen & $\begin{array}{c}\text { Serum from horses immunized } \\
\text { with other organisms }\end{array}$ \\
\cline { 2 - 3 } 1. & units per cc. & 7. & units per cc. \\
2. & 1,000 & 8. & 5,000 \\
3. & 1,000 & 9. & 200 \\
4. & 6,000 & 10. & 100 \\
5. & 10,000 & 11. & 80 \\
6. & 10,000 & 12. & 60 \\
& 50,000 & 13. & 30 \\
& & 14. & 30 \\
& & 15. & 20 \\
& & 16. & 10 \\
\hline
\end{tabular}


seems to be ample proof that antistreptolysins appear in the blood serum following streptococcal infection, and is in accord with the previous observations of Todd (4) (5).

Seventy-one specimens of blood sera were obtained during convalescence from scarlet fever patients approximately 4 weeks after the onset of the disease. It was found that the titre of the serum, as far as the antistreptolysin content was concerned, varied between 100 and 5000 units per cc. - a wide range. On the average, however, the titre was much higher than for the normals, or in the other streptococcal infections studied. Six patients had received human convalescent scarlet fever serum (30 to $55 \mathrm{cc}$.). The titre of antistreptolysin in the serum of these patients was $300,400,400,500,500$, and 800 units per cc.

The blood sera from 18 patients with erysipelas were studied during the course of their disease. The results are summarized in Table I and Figure 1. The titre varied according to the stage of the disease in which

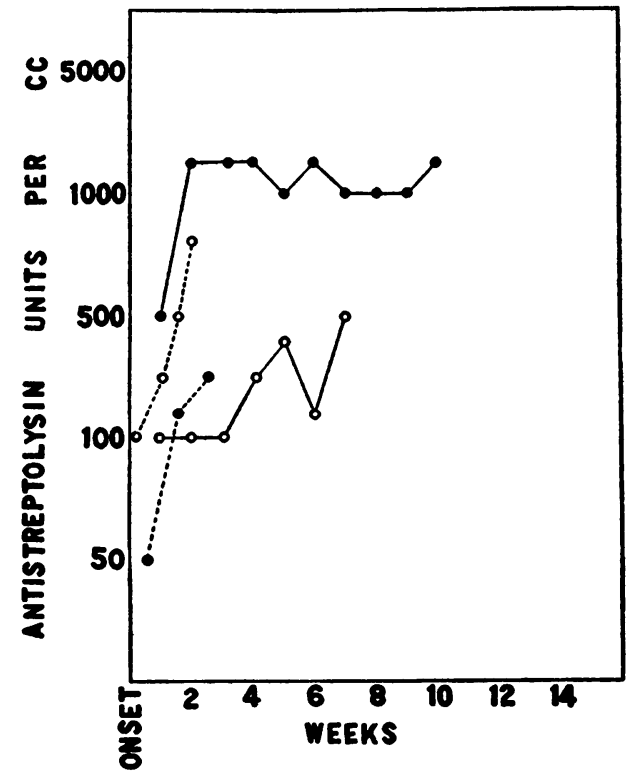

Fig. 2. The Changes in Antistreptolysin Content of the Sera from Four Patients with Erysipelas.

the determinations were made, and in different patients. Eight patients received anti-erysipelas serum, containing a high titre of antistreptolysin, early in the disease. In Table IV the titres of antistreptolysin in the sera of these patients during convalescence are compared with the antistreptolysin content of 8 patients during convalescence similarly treated except that no antisera were given. It is evident that the administration of serum 
TABLE IV

Antistreptolysin titres of serum from patients convalescing from erysipelas

\begin{tabular}{l|c||c|c}
\hline \hline Specimen & Treated with antisera & Specimen & No serum therapy \\
\cline { 2 - 4 } & units per cc. & & units per cc. \\
1. & 200 & 9. & 3000 \\
2. & 800 & 10. & 2000 \\
3. & 500 & 11. & 1000 \\
4. & 400 & 12. & 500 \\
5. & 400 & 13. & 400 \\
6. & 300 & 14. & 400 \\
7. & 300 & 15. & 200 \\
8. & 200 & 16. & 100 \\
\hline
\end{tabular}

did not influence the amount of this antibody formed as a result of the infection.

The usual course of events was to find normal or slightly increased titres at the onset of erysipelas and a gradual rise, which was maintained for some weeks. The increase in antistreptolysin titre of the sera of patients during the course of an attack of erysipelas is illustrated in Figure 2.

Acute follicular tonsillitis due to hemolytic streptococci infection was present in 19 patients whose blood serum was examined. The titre varied in individual cases from 40 to 800 units per cc. In some cases an increase in the titre was observed as the disease progressed; in others, this was not apparent.

Of the cases listed in Table I as miscellaneous streptococcal infections, there were 7 of puerperal sepsis and bacteremia, 2 of subacute bacterial endocarditis, all with $a^{\prime}$-streptococci in their blood stream. One patient had a $\beta$-hemolytic streptococcus empyema with bacteremia, and one had acute hemorrhagic nephritis with hemolytic streptococci in the throat. In these cases, there was a wide range in the titre of the blood serum, 40 to 1000 units per cc. This was true in spite of the fact that in a number of these patients the infections had been present for from 4 to 6 weeks.

It is seen then, that patients with infections due to the hemolytic streptococcus frequently develop antistreptolysins of a high titre in their blood serum. There are wide variations, and the titre may never exceed that which is found in many individuals without streptococcal infection. The highest titres were observed in patients with scarlet fever and erysipelas; somewhat lower titres occurred in acute follicular tonsillitis and in miscellaneous streptococcal infections. It was true, moreover, that the average titre of the blood serum was higher. in these groups of patients than in normal individuals.

In order to compare the titre of the blood serum from patients with proven streptococcal infections, with that from patients with other infec- 
tions, such as, pneumococcus, staphylococcus, and tubercle bacillus infection, 29 determinations were made on 14 patients with these latter conditions. The titre varied from 50 to 500 units per cc. In other. words, it was on the average lower than in proven cases of streptococcal infection.

After demonstrating that the average antistreptolysin content of the serum of patients with proven streptococcal infections was higher than in normal individuals, or in patients with other types of infection, the blood serum from patients with rheumatic fever and rheumatoid, gonococcal, and other forms of arthritis was studied in the same way. The results are summarized in Table I and Figure 1.

In selecting cases of rheumatic fever, we chose only cases in which active infection could be demonstrated either by the clinical course, as characterized by the fever, or by endocarditis, subcutaneous fibroid nodules, or electrocardiographic changes. Thirty-three cases were studied; 18 were followed for 6 weeks or longer at weekly intervals, so that the variation in the antistreptolysin titre could be observed. The titre varied from 100 to 2000 units per cc., and the variation from week to week is illustrated in Figure 3. There were observed three general types of reaction: 1) the

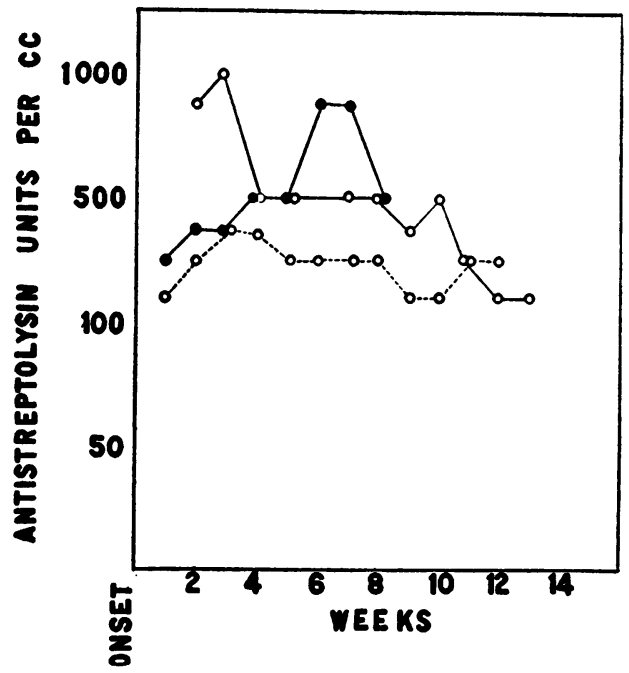

Fig. 3. The Changes in Antistreptolysin Titres of Serum from Three Patients with Rheumatic Fever.

antistreptolysin titre was higher on the first or second examination than it was on subsequent examinations, and there was a tendency for the titre to decrease from week to week, although it sometimes remained elevated for at least 10 weeks; 2) the titre was low at first and increased and remained elevated with slight fluctuation during the period of observation; and, 3) little change occurred in the titre from week to week, and the 
titre never became greater than in some normal people during a similar period of time. Indeed, in 7 of the 33 patients the antistreptolysin titre was never found to be higher than 200 units per cc. It is clear, however, that the average titre of the cases with rheumatic fever was greater than in normal individuals, and was about the same as for cases with proven streptococcal infections. This is not surprising. Inasmuch as rheumatic fever is frequently preceded by a streptococcal infection, one would expect to find a higher titre in patients who develop rheumatic fever following streptococcal infection than in those without a preceding streptococcal infection.

In the 13 cases of rheumatoid arthritis, 61 determinations were made. We selected only cases showing evidence of an active process. In most of these patients the disease had existed for many months, and there was no recent history of an acute streptococcal infection. The range of the titre of the blood serum was considerable; but on the whole, the titre was low, and the average was not greater than in normal individuals. In no case did the titre increase during observation. Thus, the findings were quite different from those in patients with proven streptococcal infections.

In 13 cases of gonococcal arthritis and in 5 cases of miscellaneous types of joint infection the titres were similar to those of rheumatoid arthritis. They were well within the normal range.

It is clear then, that the antistreptolysin content of the blood serum of patients with rheumatic fever, who have had a streptococcal infection, was comparable with the findings in patients with proven hemolytic streptococcal infection but without rheumatic fever. The titre of the sera of patients with rheumatoid, as well as other forms of arthritis, fell into a group which resembled that of normal individuals or patients with non-streptococcal infections.

\section{The relationship between the antistreptolysin titre and the agglutination reaction}

We have shown in previous work (6) that there is no direct correlation between the presence of streptococcal agglutinins in the blood serum of patients, and the skin reactions to the nucleoprotein of the same organisms. We have also demonstrated that there is no correlation between the agglutination reaction and the sedimentation rate of the red blood cells. In the present investigation, we interested ourselves in determining whether there is any relationship between the titre of the antistreptolysin and agglutinins for the streptococcus, and skin reactions to the nucleoprotein of the hemolytic streptococcus or the Dick toxin. Five hundred and thirty-six agglutination tests were done, using the same technique as described in our previous work. Two strains of hemolytic streptococci were used as antigens; one strain (NY5) was the same organism from which the streptolysin was derived, and the other (SD1), a second scarlet fever. strain. 
In the instances in which agglutinins were present in the blood serum, the antistreptolysin titre varied from 20 to 800 units per cc. The antistreptolysin titre might be low with a comparatively high agglutination and the agglutination reaction was absent or present in low titre in some patients with high titres, so that it was not possible to show any correlation between the two. This is illustrated in Figure 4.

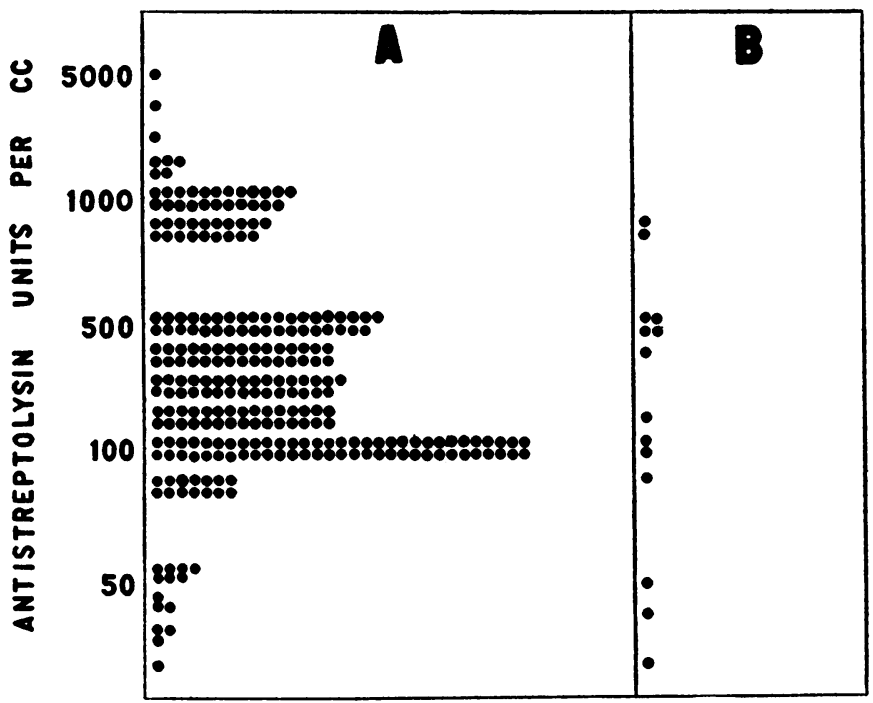

Fig. 4. The Antistreptolysin Titre and Streptococcal Agglutinins.

Each dot in Column $A$ represents the antistreptolysin content of a specimen of serum lacking streptococcal agglutinins. Each dot in Column $B$, the antistreptolysin content of a specimen of serum with agglutinins for the hemolytic streptococcus.

The relationship between the antistreptolysin titre and the skin reaction to

the nucleoprotein of the hemolytic streptococcus and to Dick toxin

In fifty-seven patients, the skin reactions to the nucleoprotein of the hemolytic streptococcus $\left(\mathrm{SD}_{1}\right)$ was studied as well as the antistreptolysin titre. The patients with negative reactions showed as high an antistreptolysin titre as those with positive skin reactions. The titre in the first group varied from 50 to 1000 units per cc., and in the latter from 20 to 1000 units per cc.

The response to Dick toxin also failed to show any correlation with the antistreptolysin content of the blood serum. The titre of the serum of 53 Dick-negative patients varied between 20 and 1000 units per cc., with an average titre of 360 units per cc. In 4 patients with positive Dick tests the serum contained $100,100,200$, and 800 units of antistreptolysin per cc. respectively. These findings are in accord with those of Todd, 
Laurent and Hill (7) who have shown that the streptolysin and Dick toxin are different substances, just as the antitoxin and antistreptolysin are different. These results are summarized in Figure 5.

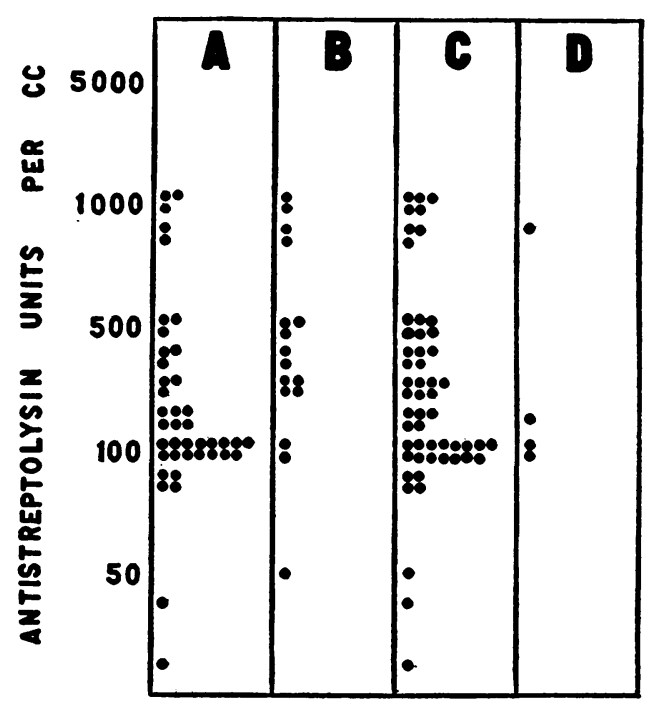

Fig. 5. Antistreptolysin Titres and Skin Reactivity to the Nucleoprotein of the Hemolytic Streptococci and to Dick Toxin.

Each dot represents the antistreptolysin titre of a serum from a patient who showed: $A$, Negative skin reaction to $.01 \mathrm{mgm}$. of the nucleoprotein of the hemolytic streptococcus; $B$, Positive reaction to $.01 \mathrm{mgm}$. of the nucleoprotein of the hemolytic streptococcus; $C$, Negative skin reaction to 1 S.T.D. of Dick toxin, and, $D$, Positive skin reaction to 1 S.T.D. of Dick toxin.

\section{COMMENT}

From the data presented, certain deductions seem justifiable. It is clear that normal individuals have antistreptolysin in their blood serum in varying amounts, and in our experience the titre may remain high for long periods of time without any evidence of active infection with hemolytic streptococci. The variations in the titre of the antistreptolysin in the blood serum of normal individuals and in patients with diseases unassociated with streptococcal infection were greater than those previously recorded in similar groups by Todd (4) (5) and Coburn and Pauli (2). In view of our own previous observation with the reactions of normal individuals to other products of the hemolytic streptococcus, such as the nucleoprotein, this great variation in normals is not surprising. It is important, nevertheless, to remember these differences in assessing the value and significance of the test under consideration.

In patients who have had recent hemolytic streptococcal infections, the antistreptolysin titre is usually higher than for the average normal indi- 
vidual, and it may increase progressively from week to week. The duration of time that the titre may remain elevated varies in individuals, and this occurs in spite of the fact that all clinical signs of hemolytic streptococcal infections have subsided. As is true with other immune reactions in patients following hemolytic streptococcal infection, there is some irregularity in the formation of antistreptolysin. Thus, we have observed patients who have had active streptococcal infections and in whom the antistreptolysin titre of the blood serum was not elevated during or following the infection.

The titres of the sera from normal individuals and the patients without infection due to hemolytic streptococci were higher on the average than have been reported by other observers (2) (4) (5). The antistreptolysin content of 200 units per cc. in our cases is the average obtained in sera from individuals without infection with the hemolytic streptococcus. Coburn and Pauli (2) accept the presence of this titre to be "a specific indication of infection with the hemolytic streptococcus."

It is not surprising that patients with rheumatic fever show an increase in the antistreptolysin titre of the blood serum as often as patients with proven hemolytic streptococcal infections, since an attack of rheumatic fever is frequently preceded by a hemolytic streptococcus infection. That 21 per cent of the group of patients with rheumatic fever failed to show titres higher than the average for the control groups, would seem to make it justifiable to question the inference that an attack of rheumatic fever is necessarily dependent on a preceding infection by the hemolytic streptococcus.

The titre of the serum of patients with active rheumatoid arthritis was in all respects similar to that for our normal individuals, patients with other types of arthritis and patients with infections not due to streptococci. In these patients, there was no history of a recent streptococcal infection, and this was supported by the low antistreptolysin titre of the blood. It seems evident that the symptoms and signs of active rheumatoid arthritis in the cases we examined were not preceded or associated with an active hemolytic streptococcus infection.

\section{SUMMARY AND CONCLUSIONS}

1. In proven hemolytic streptococcal infections the blood serum generally contains antistreptolysin in higher titre than in normal individuals or than in patients with infections caused by other micro-organisms.

2. Patients with acute rheumatic fever, who have had a streptococcal infection, have antistreptolysin titres in their sera comparable to those observed in scarlet fever, erysipelas or acute follicular tonsillitis.

3. Rheumatoid arthritis and certain other forms of joint disease are not accompanied by an increase in the antistreptolysin titre of the blood serum. 
3. Antistreptolysin was shown to be an antibody separate and distinct from streptococcal antitoxin or the antibodies responsible for streptococcal agglutination. Antistreptolysin is not related to the skin sensitivity to the nucleoprotein of the Streptococcus scarlatinae.

We acknowledge our thanks to Dr. E. H. Place of the South Department of the Boston City Hospital for convalescent scarlet fever serum, and to Dr. A. B. Wadsworth of the New York State Department of Health and Dr. W. G. Malcolm of the Antitoxin Laboratory of the Commonwealth of Massachusetts for horse sera. We also thank Miss Marjorie Jewell, Miss Eleanor Fleming and Miss Jane Locke for technical assistance.

\section{BIBLIOGRAPHY}

1 Schlesinger, B., and Signy, A. G., Precipitin reactions in the blood of rheumatic patients following acute throat infections. Quart. J. Med., n.s., 1933, 2, 255.

2. Coburn, A. F., and Pauli, R. H., Studies on the relationship of streptococcus hemolyticus to the rheumatic process. III. Observations on the immunological responses of rheumatic subjects to hemolytic streptococcus. J. Exper. Med., 1932, 56, 651.

3. Tillett, W. S., and Abernethy, T. J., Serological reactions with hemolytic streptococci in acute bacterial infections. Bull. Johns Hopkins Hosp., 1932, 50, 270.

4. Todd, E. W., Antigenic streptococcal hemolysin. J. Exper. Med., 1932, 55, 267.

5. Todd, E. W., Antihemolysin titres in hemolytic streptococcal infections and their significance in rheumatic fever. Brit. J. Exper. Path., 1932, 13, 248.

6. Keefer, C. S., Myers, W. K., and Oppel, T. W., Streptococcal agglutinins in patients with rheumatoid (atrophic) arthritis and acute rheumatic fever. J. Clin. Invest., 1933, 12, 267.

Myers, W. K., Keefer, C. S., and Oppel, T. W., Skin reactions to nucleoprotein of streptococcus scarlatinae in patients with rheumatoid arthritis and rheumatic fever. J. Clin. Invest., 1933, 12, 279.

7. Todd, E. W., Laurent, L. J. M., and Hill, N. G., An examination of the relationship between streptococcal antitoxin and antistreptolysin. J. Path. and Bact., 1933, 36, 201. 